\title{
Top-Up Model Irradiation
}

National Cancer Institute

\section{Source}

National Cancer Institute. Top-Up Model Irradiation. NCI Thesaurus. Code C161506.

An irradiation procedure in which total body irradiation is given along with an additional dose at a focal site. 